\title{
Developing Instrument to Measure Mathematical Reasoning Ability
}

\author{
Delsika Pramata Sari \\ Department of Mathematics Education \\ Indonesia University of Education \\ Bandung, Indonesia \\ delsika.math@gmail.com
}

\author{
Mahendra \\ Department of Mathematics Education \\ Indonesia University of Education \\ Bandung, Indonesia \\ miikiik_1@yahoo.co.id
}

\begin{abstract}
This research is a quantitative research, which aims to find a valid and reliable instrument for testing the mathematical reasoning ability for junior high school students. The process of analysis this instrument starting from (1) a literature review, (2) the preparation of the instrument, (3) the teoritical validity, that is testing the readability limited to five students and test the validity by experts, (4) revision, (5) the empirical validity, and (6 ) data analysis. Readability test is applied to five students with the choosen materials. Expert's judgement conducted by two supervisors, three lecturers of mathematics eduction, a junior high school math teacher, and a bahasa lecturer. Empirical validity was done in 9th grade in one of junior high schools in Bandung. The results obtained in the form of mathematical reasoning ability test instruments are valid, each coefficient validity item is more than 0.41 that mean degree of validity was high and very high. The coefficient reliability was 0.64 (more than 0.41 ) belonging to the high level of reliability. Thus, mathematical reasoning ability test can be said as valid and reliable so that it was classified as good instrument.
\end{abstract}

Keywords-instrument; mathematical reasoning ability; validity; reliability

\section{INTRODUCTION}

Mathematics is a knowledge that can improve the ability to think and to solve daily problems and the workplaces. The understanding of the mathematics prepares students for life in a modern society. PPRI Nomor 32 Tahun 2013 states that study of materials in mathematics is meant to develop logic and thinking ability [1].

Reports on Program for International Student Assessment (PISA) in 2012 stated that Indonesia's position compared to other countries in mathematical reasoning is bad. Indonesiaan students' are at position 64 of the 65 and just one level above Peru [2]. The results of the PISA study in 2015 stated that Indonesia is at position 69 of the 76 countries [3]. Based on this, achievement of Indonesian students' mathematical reasoning on any participation since 2000 is low. PISA results which are bad may indicate that (1) Indonesian students are not accustomed to resolving non routine problems, (2) Indonesian students are weak in real situations modeling to mathematical problems or in interpreting mathematical solutions to real situations, and (3) the level of reasoning, making conclusion, and analysis are very low [4]. This means that the ability to reason demanded international is higher than

what is running in the practice of mathematics in Indonesia. Instead, the world demands the skills of completing complex calculations has been reduced [4]. PISA uses non routine problem that test the reasoning ability [5]. This indicates that student's mathematical reasoning abilities in Indonesia are still low. In fact, the mathematical reasoning ability has become one of the educational goals in many countries.

The quality of teaching junior high school studied and in comparison with other junior high schools in the regency/city, provincial, and national. Some of the statements contained in the principal results of Ujian Nasional (UN) 2013/2014 as follows: (1) the average value of junior high school students surveyed in each math topic is still low, (2) the average value junior high school students studied math is lower than the average value of the city, and National.

The data above shows that there are problems in the school. Based on results of the study Pusat Pengembangan dan penatara Guru (PPPG) 2002, contained a statement that the mathematics teacher in Indonesia tend to have problems in teaching mathematics because students' mathematical ability is still low [6]. Similarly, Trend in International Mathematics and Science Study (TIMSS) 2011 report revealed that for the type of questions of reasoning, Indonesian students tend to have a value below the average International [7]. Through the UN 2013/2014 shows that the junior high school students studied had low levels of reasoning. Then, through a preliminary study by giving students mathematical reasoning test, obtained the fact that junior high school students who studied have low in mathematical reasoning. Mathematical reasoning means: (1) transduction: drawing conclusions from a single case or a specific nature that is applied to other cases, (2) generalization: a general conclusion based on the number of observed data, and (3) carry out calculations based on specific rules or formulas [8]. In addition, through interviews with teachers obtained information that the students had low mathematical reasoning abilites. The low reasoning ability junior high school students who studied due to learning occurs in the classroom still tends to be concentrated to teachers (teacher centered) so that students don't have opportunity to discuss and develop reasoning through his own mind.

Basically, any settlement requires math reasoning abilities. Through reasoning, students can see that mathematics is the study of a reasonable or logical thing. In modern life is already available calculators to calculate, but the machine has not been able to replace humans in thinking [5]. Intelligent life of the nation requires prosperous reasoning culture. This is reinforced by the Organization for Economic Cooperation and 
Development (OECD), which states that the reasoning is the mathematical skills that are used in all phases and different activities as well as related to mathematical reasoning. Reasoning ability is rooted in logical thinking process to analyze the information, to explore, and connect the basic of the problem which can lead to reasonable conclusions, examine the base of truth given, or provide the truth of the statement or the solution of the problem [9].

Reasoning is a process of drawing conclusions from information that is not static [10]. The ability of mathematical reasoning is part of mathematical skills which are used in all phases and different activities and also relate to mathematical literacy. Reasoning ability is rooted in logical thinking process that explores and connects basic of the problem so that it can generate a reasonable conclusion, examine the truth, or prove the truth of statement or solution. Improving the ability of mathematical reasoning provides benefits that can form good mindset for students to deal with real-world problems either now or when they have joined into the community.

Mathematical reasoning ability instrument in this research in different from anothers. The difference in this study is in the indicator that was used. One of mathematical reasoning ability indicator is transduction that rare to be used in anothers research.

Transduction mostly used in biology, not in mathematics. The idea of transduction is used in solving problem, such as genetic analysis, microbial genetics (gene transfer), bacterial transduction. In mathematics, transduction is used when solving a given problem one should avoid solving a more general problem as an intermediate step. The reasoning behind this principle is that in order to solve the more general task resources may be wasted or compromises may have to be made which would not have been necessary for the solution of the problem at hand. In Indonesia, there are rare to find transduction as mathematical reasoning indicator. As examples, mathematical reasoning indicator that researchers develop by [11], [12], [13], and [14] was not use transduction. furthermore, transduction is useful tool to solve problem many mathematical problem.

In the following, presented example in item test.

A three dimensional solid object $A B C D . E F G H$ has 12 edges. $\overline{A B}, \overline{C D}, \overline{E F}$, and $\overline{G H}$ are parallel each other and equal in length. $\overline{A E}$ is parallel and equal in length to $\overline{C G} . \overline{A D}$ is parallel and equal in length to $\overline{F G} \cdot \overline{A B}$, $\overline{A E}$, and $\overline{A D}$ are not parallel and unequal in length.

a. Draw a three dimensional solid object $A B C D . E F G H$ !

b. Write three pairs of faces are parallel and congruent!

Based on the description above, it is necessary to develop mathematical reasoning abilities in students' learning and innovation efforts in order to improve mathematical abilities. One such effort is to improve learning evaluation system and it is useful to know how far the achievement of learning objectives which are the implementation of educational goals. The evaluation includes comparing something with the same measuring instrument, then take a decision of something with measure a good or bad [15]. One thing that can be seen from these evaluations is the student's mathematical reasoning abilities.

To measure the student's mathematical reasoning abilities, it needs to be developed a test instrument. An instrument test is good if it has validity and reliability at the medium category (more than 0.41). The steps in the preparation of the test include: (1) determine the purpose of holding the test, (2) impose restrictions on the materials that will serve as a test, (3) formulating instructional objectives, (4) makes grating instrument, (5) making items based on aspects and indicators to be measured [15]. The instrument was developed to measure the ability of mathematical reasoning in the form of subjective tests as essay form.

\section{RESEARCH METHOD}

This research used the Research and Development method. Object of this research was mathematical reasoning ability test with the geometry material on the essay form. In the first step of developing the instrument, conducted a theoretical overview by reviewing the literature related to mathematical reasoning abilities. Second, arranged the grating and instruments based on the theory. After that, did the validation process. Theoretically, the readability test is limited to five students and expert validity (judgement). Theoretical validation by the experts was done by providing a file that consists of a grating instrument, instrument in the form about the description, and the validation sheet.

Things must be considered for the theoretical validity are: (1) the accuracy of instruments are observed from the evaluated materials whether they are used as an evaluation tool is a representative sample of the knowledge that must be mastered and whether the formulation of test items in accordance with the indicator and (2) the validity of the arrangement of sentences or words gives clear understanding or does not cause any other suggestion from experts on instruments taken into consideration for repairment. After the theoretical validation process is done, and then doing the empirical validation process, that is the test instrument for 22 students (testee) spend time 80 minutes. Then, analize the data.

The data were obtained from a good instrument. Test instruments for analysis tested the validity, reliability, discrimination index, and level of difficulty (difficulty index) about using Anates V4. Validity is the important idea to consider in preparing or selecting the instruments to be used [16]. The validity of an instrument is the accuracy/precision of the measuring instrument/uncovering of what should be measured/revealed. Validity obtained through Theoretical validity and Empirical validity. The validity of theoretical is done by (1) the instrument is read by five students who have studied the material with connect to this research, to see whether the instrument which has been prepared can be understood by students both in terms of content and language, and (2) the instrument read by experts which becomes validate instruments, the validator is chose based on the background of different skills that spreads the appropriate field of study, testing the validity of the expert in the study is conducted by two supervisors, three lecturers of mathematics education, a 
mathematics teacher of junior high school, and a bahasa lecturer. In the other hand, an instrument has empirical validity when it is tested on the experience [11]. The relevant formula in this case is the formula Pearson Product Moment correlation [15].

Reliability means that the score of the instrument is stable and consistent [14]. Alpha formula $\left(\mathrm{r}_{11}\right)$ can be used to test reliability [17]. Discrimination index is an ability of the matter/problem to differ high-ability students from low-ability students [15]. Discrimination index is formulated as reduction of the correct number for the above group by the number of students from bottom group, and the result must be devided by the number of students from above/bottom group [17]. And the last, criteria in difficulty index: good question is a question that is not too easy or too difficult.

\section{RESULTS AND DISCUSSION}

Analysis result of theoretical validity are: (1) instrument was read by five students who are non testee stated that they understood and the problem is clear, and (2) the instrument read by experts who are instruments validator (expert's judgement). The validator including supervisor I, supervisor II, expert of mathematics, expert of evaluation, expert of learning, math teacher, and expert of Bahasa.

Supervisor I gave comment: change editorial logical sentence. Supervisor II gave comment Changes editorial logical sentence. Expert of mathematics gave comment: one matter to measure one indicator alone, Question 3 is not identifically use aspects of inductive reasoning or deductive reasoning. Expert of evaluation gave comment in number 1: needs improvement editorial about the command. Question 3: the word "tempat" was changed to "wadah" and commands about ambiguous, so it needs to be fixed. Expert of learning gave comment in number 1: name ABCD.EFGH geometry and ribs name written in Equation Editor, and question 3: description of information need to be increased from the conversion of liters to $\mathrm{cm}^{3}$. Math teacher gave comment: writing ribs names alphabetically, images do not separate from matter, scale the image to be adjusted to its size, as well as the improvement of the structure of the sentence. Expert of Bahasa gave comment: changes editorial sentences and the use of Bahasa that is not according to the rules of Indonesian grammar correctly.

Based on the theoretical validation above, test questions mathematical reasoning abilities are fixed according to the suggestion from validators, which are then discussed again with the supervisor. Next, doing empirical validation or testing to testee in school.

After testing the instrument, then it is implemented calculating the validity, reliability, discrimination features, and level of difficulty of test mathematical reasoning, questions which use Anates V4. Instruments are good if the coefficients validity and reliability above 0.41 . It is expected on the instrument that has been made, so that it can generate good data. Recapitulation of the results of analyzes of mathematical reasoning abilities trial test with Anates V4 as follows.
TABLE I. RECAPITULATION EMPIRICAL VALIDATION OF MATHEMATICAL REASONING ABILITY TEST

\begin{tabular}{|c|c|c|c|c|c|c|c|c|}
\hline \multirow{2}{*}{ No } & \multicolumn{2}{|c|}{ Validity } & \multicolumn{2}{|c|}{ Reliability } & \multicolumn{2}{|c|}{ DP } & \multicolumn{2}{|c|}{ IK } \\
\hline & Val & Int & Val & Int & Val & Int & Val & Int \\
\hline 1 & 0,821 & $\begin{array}{l}\text { Very } \\
\text { High }\end{array}$ & \multirow{5}{*}{0,64} & \multirow{5}{*}{ High } & 0,556 & Good & 0,667 & Medium \\
\hline 2 & 0,710 & $\begin{array}{l}\text { Very } \\
\text { High } \\
\end{array}$ & & & 0,667 & Good & 0,556 & Medium \\
\hline 3 & 0,637 & High & & & 0,222 & Medium & 0,167 & Difficult \\
\hline 4 & 0,602 & High & & & 0,333 & Medium & 0,278 & Difficult \\
\hline 5 & 0,682 & High & & & 0,611 & Good & 0,528 & Difficult \\
\hline
\end{tabular}

Val: Value, Int: Interpretation, DP: Discrimination Index, IK: Difficulty index

\section{CONCLUSIONS}

The results of theoretical validity analysis by the validator found that mathematical reasoning ability test instrument has been declared as valid. Furthermore, the results of the analysis showed that the empirical validation of test valid mathematical reasoning abilities with coefficient validity of each item more than 0.41 and it was categorized as high and very high validity. Coefficient reliability was 0.64 (more than 0.41 ) that belong to a high level of reliability. Values of difficulty index describes two questions as difficult and three questions as medium. Values of discrimination index describe two questions as medium categories and three questions as good category. Thus, it can be concluded that the mathematical reasoning ability tests were classified as good instruments, meant valid and reliable.

\section{Acknowledgment}

Thanks to Indonesia University of Education and the lecturers of mathematics education graduate inspiring, especially Prof. Dr. H. Darhim, M.Si. and Dr. Rizky Rosjanuardi, M.Si. Thanks to PPTK which gives scolarship and support my study in Indonesia University of Education. Thanks to SMP Laboratorium UPI that fasilitates the study.

\section{References}

[1] Peraturan Pemerintah Nomor 32 Tahun 2013 (revisi PP Nomor 19 Tahun 2005) tentang Standar Nasional Pendidikan.

[2] OECD, "PISA 2012 Results in Focus: What 15-Year-Olds Know and What They Can Do with What They Know," Paris, France: OECD, 2015 .

[3] S. Coughlan, “Asia Tops Biggest Global School Rankings,” Retrieved from http://www.bbc.com/news/business-32608772, 2015.

[4] I. Pranoto, "UN Matematika Menyiapkan Anak Indonesia menjadi Kuli Nirnalar: Republik Telah Menyerobot Kesempatan Anak Bangsa Bernalar," Retrieved from http://www.slideshare.net/y0r/un-matematikamenyiapkan-anak-menjadi-kuli-nirnalar, 2011.

[5] I. Pranoto, "Kasmaran Bermatematika," Retrieved from http://www.bincangedukasi.com/kasmaran-bermatematika/, 2013.

[6] PPPG, “Laporan Monitoring dan Evaluasi Program Pasca Penataran PPPG Matematika “, Yogyakarta, 2002

[7] TIMSS, “TIMSS 2011 International Results in Mathematics", Retrieved from http://timssandpirls.bc.edu/timss2011/international-resultsmathematics.html, 2011

[8] U. Sumarmo, "Berpikir dan Disposisi Matematik serta Pembelajarannya”, Bandung: Universitas Pendidikan Indonesia, 2015

[9] OECD, "Draft PISA 2015 Mathematics Framework," Paris, France: OECD, 2013.

[10] D. F. Lohman and J. M. Lakin, “ Reasoning and Intelligence," Retrieved 
http://faculty.education.uiowa.edu/dlohman/pdf/Reasoning\%20and\%20I ntell_Lohman\%20Lakin\%20102709.pdf, 2013.

[11] N. Andriani, "Pembelajaran dengan Menggunakan Resourse-Based Learning untuk Meningkatkan Kemampuan Penalaran dan Pemecahan Masalah Matematis Siswa SMP Kelas VIII,” Bandung: SPs UPI, 2011.

[12] M. S. Rohmah, "Pendekatan Brainstorming Teknik Round-Robin unuk Meningkatkan Kemampun Penalaran, Komunikasi Matematis, dan Self Awareness Siswa SMP,” Bandung: SPs UPI, 2013.

[13] J. Rahmatudin, "Penerapan Model Pembelajaran Search, Slve, Create, and Share untuk Meningkatkan Kemampuan Penalaran Matematis Self Concept Siswa SMP Negeri 1 Kedawung,” Bandung: SPs UPI, 2013.
[14] N. Widyasari, "Meningkatkan Kemampuan Penalaran dan Disposisi Matematis Siswa SMP melalui Pendekata Metaphorical Thinking," Bandung: SPs UPI, 2013.

[15] S. Arikunto, "Dasar-Dasar Evaluasi Pendidikan (Ed.2)," Jakarta: Bumi Aksara, 2013.

[16] J. R. Fraenkel and N. E. Wallen, "How to Design and Evaluate Reasearch and Education," 7th ed., New York, NY: McGraw-Hill Higher Education, 2013.

[17] E. Suherman, "Evaluasi Pembelajaran Matematika," Dalam Turmudi. ed., Bandung: UPI, 2003. 